\title{
Model Sinergitas Pengarusutamaan Gender dalam Mewujudkan Keadilan dan Kesetaraan Pendidikan
}

\author{
NURSINI TAWAKKAL, ${ }^{1}$ RAHIM DARMA, ${ }^{2}$ SRI UNDAI NURBAYANI ${ }^{3}$ \\ 1), 3) Fakultas Ekonomi, Universitas Hasanuddin, Jl Perintis Kemerdekaan Tamalanrea KM 10, Makassar \\ 2) Fakultas Pertanian, Universitas Hasanuddin. Jl Perintis Kemerdekaan Tamalanrea KM 10, Makassar \\ ${ }^{1}$ nini_mahmud@yahoo.com; ${ }^{2}$ rdarma@indosat.net.id; ${ }^{3}$ sri.undai@gmail.com
}

\begin{abstract}
This research aims to: (1) to analyze the causes of the gender gap in education, (2) to analyze the extent to which respondents' knowledge about gender and gender responsive education, (3) to build model gender mainstreaming to achieve gender justice and equality in education. The data used are primary and secondary data which were analyzed descriptively. Locations of the study are the village Pabiringa and Biringkassi in Jeneponto and Tompobalang in Gowa, South Sulawesi Province The result showed that: (1) the causes the gender gap in education is a factor of participation, access, control, and culture, (2) understanding the respondents about gender and gender-minded education is still low, (3) the model was developed to achieve gender justice and equality in education is a model institutional strengthening of gender mainstreaming based-synergy between teachers, Parents, and the Department of Education
\end{abstract}

Key word: Model, Gender, Mainstreaming, bias, education

\begin{abstract}
Abstrak. Penelitian ini bertujuan untuk: (i) menganalisis faktor penyebab kesenjangan gender di bidang pendidikan, (2) menganalisis sejauhmana pemahaman responden tentang gender dan pendidikan yang berwawasan gender, (3) mengembangkan model pengarusutamaan gender dalam rangka mewujudkan keadilan dan kesetaraan gender di bidang pendidikan. Data yang digunakan adalah data primer dan sekunder yang dianalisis secara deskriptif. Lokasi penelitian adalah Desa Pabiringa dan Biringkassi di Kabupaten Jeneponto dan Desa Tompobalang di Kabupaten Gowa, Provinsi Sulawesi Selatan. Hasil penelitian menunjukkan bahwa: (1) penyebab kesenjangan gender di bidang pendidikan adalah faktor partisipasi, akses, kontrol, dan budaya masyarakat, (2) pemahaman responden tentang gender dan pendidikan berwawasan gender masih rendah, (3) Model yang dikembangkan untuk mewujudkan keadilan dan kesetaraan gender bidang pendidikan adalah model penguatan kelembagaan pengarusutamaan gender berbasis sinergitas antara guru, Orang Tua Murid, dan Dinas Pendidikan
\end{abstract}

Kata Kunci: Model, Pengarusutamaan, Gender, bias, pendidikan.

\section{Pendahuluan}

Beberapa tahun terakhir ini, pemerintah Provinsi Sulawesi Selatan telah memperlihatkan keberhasilan dalam mendorong kesetaraan gender yang terlihat pada perkembangan angka indeks pembangunan gender (IPG) dan Indeks Pemberdayaan Gender (IDG). Pada tahun 2009, IPG sebesar 62,07 dan IDG sebesar 53,82 meningkat masingmasing menjadi 63,50 dan 63,88 pada tahun 2012. Meskipun kecenderungan IPG dan IDG mengalami peningkatan, namun posisinya masih berada dibawah rata-rata nasional. Rendahnya posisi IPG dan IDG di Sulawesi
Selatan terutama disebabkan oleh rendahnya capaian indikator pada bidang pendidikan khususnya angka buta huruf perempuan yang tergolong sangat tinggi.

Dengan mencermati indikator pendidikan yang responsive gender, Sulawesi Selatan masih menghadapi masalah bias gender yaitu: (i) Jumlah anak laki-laki yang putus sekolah lebih tinggi daripada perempuan pada kedua golongan umur 7-12 dan 13-15 tahun yang tersebar pada seluruh kabupaten/ kota di Sulawesi Selatan; (ii) Jumlah penduduk perempuan yang lulus lebih tinggi daripada

Received: 9 Januari 2015, Revision: 5 April 2015, Accepted: 23 Mei 2015

Print ISSN: 0215-8175; Online ISSN: 2303-2499. Copyright@2015. Published by Pusat Penerbitan Universitas (P2U) LPPM Unisba Terakreditasi SK Kemendikbud, No.040/P/2014, berlaku 18-02-2014 s.d 18-02-2019 
laki-laki pada tahun 2009 yang tersebar pada jenjang SD, SMP, MI dan MTs; (iii) Penduduk perempuan yang melek huruf $(86,64)$ lebih rendah dibandingkan dengan laki-laki $(91,23)$ pada tahun 2012 atau dengan kata lain, perempuan yang buta huruf lebih banyak daripada penduduk laki-laki dan kenyataan ini tersebar di seluruh kabupaten/kota Sulawesi Selatan; (iv) Angka partisipasi sekolah (APS) perempuan relatif lebih tinggi dibandingkan dengan laki-laki pada semua kelompok umur menurut jenjang pendidikan. Akan tetapi pada tahun 2010, angka partisipasi murni laki-laki lebih tinggi daripada perempuan.

Berbagai kenyataan ketimpangan gender di bidang pendidikan di Sulawesi Selatan, mensyaratkan masih perlu upaya yang serius bagi seluruh pemangku kepentingan untuk terus menggalakkan strategi pengarusutamaan gender (PUG) secara berkelanjutan. Salah satu upaya cukup signifikan untuk mengatasi kesenjangan gender bidang pendidikan adalah mengembangkan model penguatan kelembagaan pengarusutamaan gender di bidang pendidikan berbasis sinergi antara guru, orang tua murid, dan pemerintah (Dinas Pendidikan).

Studi ini menjelaskan tiga hal yaitu (1) menganalisis faktor penyebab kesenjangan gender bidang pendidikan yang berfokus pada empat faktor yaitu akses, partisipasi, kontrol, dan manfaat terhadap pendidikan di Kabupaten Gowa dan Jeneponto; (2) menganalisis tingkat pemahaman orang tua murid tentang pengertian gender dan pendidikan yang berwawasan gender; (3) mengembangkan model penguatan kelembagaan PUG untuk mewujudkan kesetaraan dan keadilan gender bidang pendidikan.

Data yang digunakan adalah data sekunder dan primer. Data sekunder diperoleh dari BPS dan Dinas Pendidikan seperti Daerah dalam angka. Data primer diperoleh dari hasil wawancara kepada orang tua murid dan key informan (guru dan staf Dinas Pendidikan). Teknik pengumpulan data primer dilakukan secara random. Data yang terkumpul dianalisis secara kualitatif dan statistik-deskriptif. Lokasi penelitian yaitu Desa Pabiringa dan Desa Biringkasi di Kabupaten Jeneponto dan Desa Tompobalang di Kabupaten Gowa.

\section{Gambaran Umum Pendidikan}

Gambaran umum pendidikan yang diuraikan disini adalah tingkat pendidikan anak didik dari seluruh responden. Hal ini dimaksudkan untuk mengetahui lebih jauh tentang status pendidikan anak bagi mereka apakah masih sekolah, atau putus sekolah ataukah tamat sekolah menurut jenjang pendidikan. Secara keseluruhan (dua lokasi penelitian) tercatat jumlah anak seluruh responden sebanyak 175 orang yang terdiri atas perempuan sebanyak 80 orang dan laki-laki 95 orang. Jumlah anak responden yang menempuh pendidikan sekolah dasar (SD) lebih mendominasi dibandingkan dengan jenjang pendidikan lainnya (termasuk

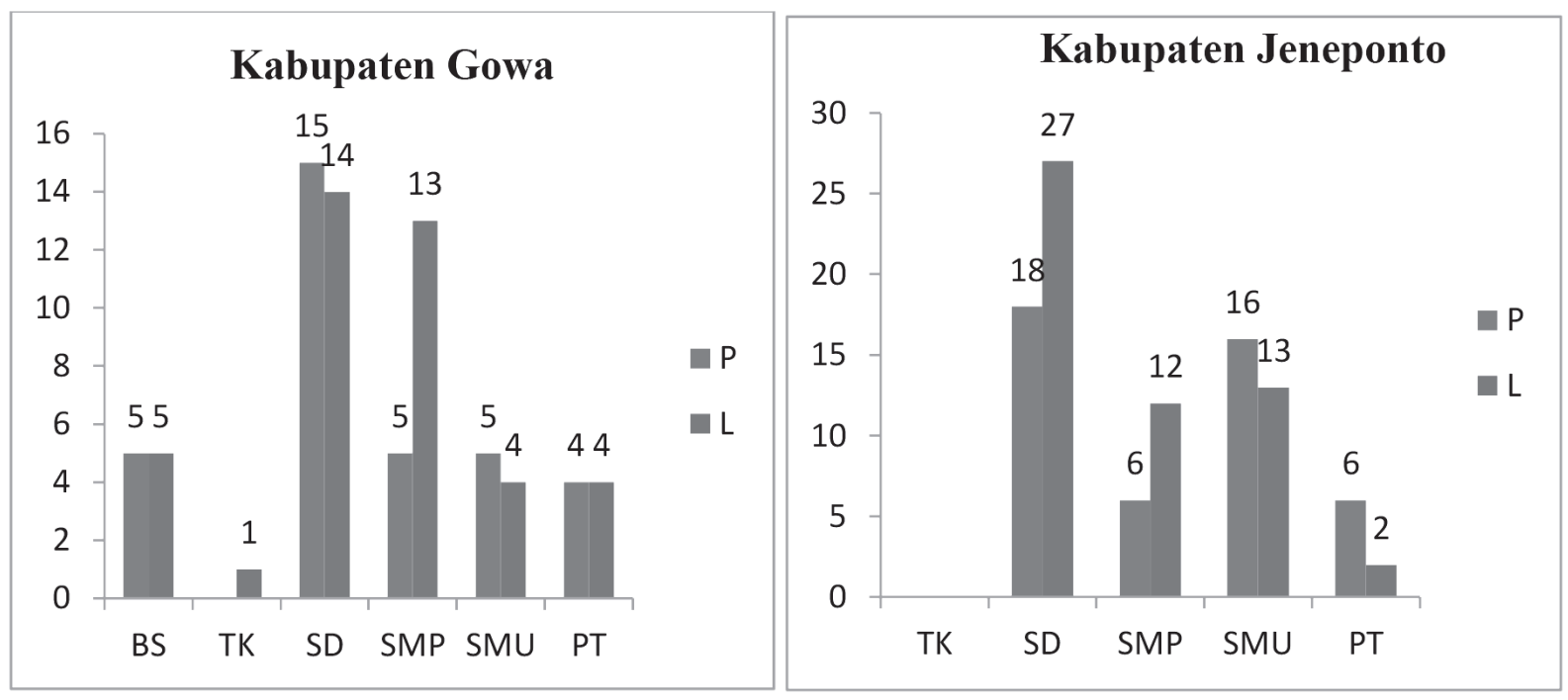

Gambar 1 Pendidikan Anak Responden per jenjang sekolah, di Kab Gowa dan Jeneponto

Sumber : Data Primer, diolah 2014. Keterangan: jumlah anak sekolah termasuk sedang bersekolah, putus sekolah, tamat sekolah, belum sekolah per jenjang pendidikan 
didalamnya masih sekolah, putus sekolah, dan tamat sekolah) sebagaimana terlihat pada Gambar 1. Di Kabupaten Gowa, jumlah anak responden pada jenjang SD sebanyak 29 orang terdiri dari 15 perempuan dan 14 laki-laki, sementara di Jeneponto sebanyak 27 laki-laki dan 18 perempuan. Di Kabupaten Jeneponto terdiri atas 27 laki-laki dan 18 perempuan. Untuk jenjang pendidikan SMP sebanyak 36 orang yang terdistribusi pada Laki-laki sebanyak 12 orang di Jeneponto dan 13 orang di Gowa dan perempuan sebanyak 5 orang di Gowa dan 6 orang di Jeneponto. Yang menarik adalah terdapat 16 anak didik responden yang menempuh pendidikan hingga Perguruan Tinggi (PT) masing-masing 8 orang dimana jumlah perempuan lebih banyak daripada laki-laki.

Ini mengindikasikan bahwa masyarakat di wilayah penelitian ini telah menyadari arti pentingnya pendidikan. Berdasarkan wawancara dari salah seorang responden mengatakan bahwa pendidikan bagi anak sangat penting karena mereka tidak menginginkan anaknya nanti mengikuti jejak orang tuanya yang tidak pernah duduk dibangku sekolah. Jika dicermati status pendidikan anak didik, terlihat bahwa jumlah anak didik yang masih menduduki bangku sekolah lebih tinggi daripada yang tamat sekolah dan lebih banyak pada bangku sekolah dasar dibandingkan dengan jenjang pendidikan SMP, SMA, dan PT terlihat pada Tabel 1. di Kabupaten Jeneponto, dari seluruh responden tercatat jumlah anak didik yang masih menduduki bangku sekolah (TK, SD, SMP, SMA, PT) sebanyak 39 perempuan dan 38 orang laki-laki, sementara di Gowa terdiri atas 21 orang perempuan dan 23 orang laki-laki. Hal ini berarti terdapat kecenderungan kesetaraan antara anak laki-laki dan perempuan menduduki bangku sekolah.

Hal yang menarik adalah masih ditemukan status anak yang putus sekolah di kedua lokasi penelitian. Jumlah anak yang tidak tamat sekolah sebanyak 10 orang di Kabupaten Jeneponto dan sebanyak 5 orang di Kabupaten Gowa. Jika dicermati berdasarkan jenis kelamin, jumlah anak laki-laki yang putus sekolah lebih banyak daripada anak perempuan. Untuk di Jeneponto, anak yang putus sekolah ditemukan pada SD, SMP, dan SMU, sementara di Kabupaten Gowa hanya di tingkat SD dan PT.

Berdasarkan hasil wawancara responden di Desa Tompobalang Kabupaten Gowa, bahwa anak yang tidak tamat sekolah tersebut terjadi pada puluhan tahun yang lalu, bukan kondisi sekarang. Terjadinya anak putus sekolah pada kondisi yang lalu disebabkan oleh faktor biaya dan faktor budaya. Karena faktor biaya dan faktor budaya, maka anak perempuan cenderung dinikahkan lebih cepat meskipun masih dalam status anak masih bersekolah, sementara kalau anak laki-laki harus mencari nafkah untuk membantu orang tuanya. Untuk kondisi sekarang, masih ada kasus "anak didik putus sekolah" khususnya pada jenjang SD terutama anak perempuan. Anak tersebut putus sekolah bukan disebabkan oleh faktor biaya dan budaya tetapi lebih disebabkan oleh mental anak (informasi dari salah satu Guru SD Cambaya).

Tabel 1

Status Pendidikan anak responden menurut jenis kelamin, 2014

\begin{tabular}{|c|c|c|c|c|c|c|c|c|c|}
\hline \multicolumn{7}{|c|}{ Kabupaten Jeneponto } \\
\hline $\begin{array}{c}\text { Kategori } \\
\text { Sekolah }\end{array}$ & \multicolumn{3}{|c|}{ Perempuan } & \multicolumn{5}{|c|}{ Laki-Laki } & Jumlah \\
\hline & S & T & TT & BS & S & T & TT & BS & \\
\hline SD & 18 & & & & 24 & & 3 & & 45 \\
\hline SMP & 6 & & & & 3 & 7 & 2 & & 18 \\
\hline SMU & 10 & 3 & 3 & & 10 & 1 & 2 & & 29 \\
\hline PT & 5 & 1 & & & 1 & 1 & & & 8 \\
\hline Jumlah & 39 & 4 & 3 & 0 & 38 & 9 & 7 & & 100 \\
\hline \multicolumn{8}{|c|}{ Kabupaten Gowa } \\
\hline \multicolumn{8}{|c|c|c|c|c|c|c|c|c|c|c|c|}{} \\
\hline TK & S & T & TT & BS & S & T & TT & BS & \\
\hline SD & 11 & 2 & 2 & & 12 & 1 & 1 & & 29 \\
\hline SMP & 5 & & & & 6 & 7 & & & 18 \\
\hline SMU & 2 & 3 & & & 3 & 1 & & & 9 \\
\hline PT & 3 & 1 & & & 1 & 1 & 2 & & 8 \\
\hline BS & & & & 5 & & & & 5 & 10 \\
\hline Jumlah & 21 & 6 & 2 & 5 & 23 & 10 & 3 & 5 & 75 \\
\hline
\end{tabular}

Sumber: Data Primer diolah, 2014

Keterangan : $\mathrm{S}=$ sedang bersekolah/kuliah, $\mathrm{T}=$ tamat, $\mathrm{T}=$ Tidak Tamat, $\mathrm{BS}=$ Belum Sekolah

Untuk di Kabupaten Jeneponto (Desa Pabiringa dan Biringkasi), penyebab terjadinya putus sekolah hampir sama dengan kasus di Desa Tompobalang di sekitar SD Inpres Cambaya, Gowa yaitu faktor ekonomi, faktor budaya, dan faktor lingkungan. Terdapat kecenderungan anak laki-laki lebih senang bekerja sebagai abo-abo atau pengumpul rumput laut untuk membantu orang tuanya. Kondisi ini pada umumnya terjadi di wilayah pesisir yang sebagian masyarakatnya memunyai kemampuan ekonomi yang sangat terbatas sehingga anak laki-laki menjadi tumpuan harapan mereka. Selain faktor ekonomi, juga ditemukan informasi bahwa 
seorang siswa putus sekolah karena merasa dirinya kurang mampu dibandingkan dengan teman-teman sekelasnya. Secara umum di kedua lokasi penelitian, beberapa faktor yang turut berkontribusi terhadap anak didik untuk tidak bersekolah antara lain faktor ekonomi (sekitar 50\% responden mengatakan bahwa masalah biaya merupakah faktor penghambat utama dalam melanjutkan pendidikan), faktor jarak dan masalah internal rumah tangga termasuk faktor budaya sekitar 25,3 $\%$ responden, selebihnya faktor lainnya termasuk lingkungan sebanyak 24,7\%.

Dengan memerhatikan jumlah anak didik berdasarkan status pendidikan dapat disimpulkan bahwa di kedua lokasi penelitian masih terdapat kesenjangan gender terutama pada anak yang putus sekolah. Faktor penyebab putus sekolah selain karena motif ekonomi dan budaya juga karena faktor akses, partisipasi, kontrol, dan manfaat terhadap pendidikan dan fasilitas pendidikan. Keempat faktor tersebut erat kaitannya dengan orang tua dan guru sekolah.

\section{Analisis Faktor Penyebab Kesenjan- gan Gender di Bidang Pendidikan}

Analisis faktor penyebab ketimpangan gender difokuskan pada empat aspek yaitu akses, partisipasi, kontrol, dan manfaat. Terkait dengan penelitian ini, data dan informasi ke-4 aspek tersebut diperoleh dari orang tua murid dan guru sekolah. Yang dimaksud dengan "akses" dalam penelitian ini adalah peluang anak didik (laki dan perempuan) untuk bersekolah mulai dari SD hingga Perguruan Tinggi dan peluang anak didik (laki dan perempuan) dalam mendapatkan fasilitas di sekolah. Untuk informasi akses dapat diperoleh dari orang tua dan guru misalnya perlakuan orang tua memberikan kesempatan anak didik perempuan dan laki untuk menempuh pendidikan, perlakuan guru terhadap anak didik laki dan perempuan mengakses fasilitas pendidikan. Jika ada orang tua memberikan perlakuan yang berbeda antara lakilaki dan perempuan untuk bersekolah maka kondisi tersebut merupakan salah satu penyebab ketimpangan gender bidang pendidikan. Partisipasi di bidang pendidikan adalah keterlibatan anak didik laki dan perempuan untuk menempuh pendidikan. Meskipun orang tua dan guru telah memberikan kesempatan atau perlakuan yang sama bagi anak didik untuk bersekolah dan mengakses sarana dan prasarana pendidikan namun belum tentu anak didik tersebut berpartisipasi atau mau/ ingin bersekolah. Mungkin terdapat diantara mereka yang lebih berpartisipasi. Dalam penelitian ini partisipasi dapat dianalisis pada partisipasi orang, partisipasi anak didik, dan partisipasi guru antara lain partisipasi anak didik untuk rajin ke sekolah, rajin belajar, mengerjakan pekerjaan rumah, partisipasi untuk memanfaatkan ruang baca misalnya perpustakaan sekolah, dan keterlibatan orang tua membantu atau memberi motivasi anak, keterlibatan guru dalam memberi motivasi anak sehingga tidak putus sekolah atau motivasi untuk rajin belajar, dsb.

Faktor kontrol dikaitkan dengan pendidikan adalah tindakan orang tua (suami dan ibu) dalam menentukan anak untuk bersekolah pada jenjang pendidikan, pengawasan orang tua terhadap pendidikan, dan juga pengawasan dari guru sekolah. Dan terakhir adalah faktor manfaat yaitu kemanfaatan fasilitas bagi anak didik di sekolah, kemanfaatan pendidikan gratis bagi anak didik dan bagi orang tua murid, dan kemanfaatan pendidikan bagi anak didik setelah bersekolah, dan sebagainya.

Berbasis dari hasil wawancara dengan responden baik dari pihak sekolah, guru wali kelas maupun guru mata pelajaran lainnya serta orang tua siswa secara umum ditemukan bahwa di lokasi penelitian terdapat ketimpangan gender dari aspek prilaku, jumlah anak putus sekolah, dan prestasi anak didik laki-laki dan perempuan di sekolah. Ada beberapa kecenderungan yang ditemukan yaitu, (1) Kecenderungan anak didik perempuan lebih rajin, lebih tekun, dan lebih aktif di kelas dibandingkan dengan anak didik laki-laki; (2) Tingkat prestasi yang dicapai oleh anak didik perempuan lebih tinggi daripada anak didik laki-laki; (3) jumlah anak laki-laki yang putus sekolah lebih banyak dibandingkan dengan anak didik perempuan. Pertanyaannya adalah apakah ketimpangan gender tersebut disebabkan oleh faktor akses, partisipasi, kontrol, dan manfaat terhadap pendidikan dan prasarana pendidikan atau faktor lainnya seperti lingkungan, budaya, ekonomi, dan mental anak. Temuan di lapangan menunjukkan bahwa ketimpangan gender di bidang pendidikan disebabkan sebagian disebabkan oleh faktor akses, faktor partisipasi dan faktor budaya, serta faktor ekonomi. Studi ini sejalan dengan studi yang dilakukan oleh Rahminawati, (2001); Fitrianti dan Habibullah, (2012); Natasha, (2013); Ichwayudi, (2013); dan Mufidah (2011) serta beberapa studi lainnya bahwa ketimpangan gender di bidang pendidikan 
sebagian disebabkan oleh faktor budaya dan faktor akses serta faktor lainnya.

\section{Faktor Akses terhadap Pendidikan dan Fasilitas Pendidikan}

Faktor akses disini dapat dianalisis pada dua aspek yaitu akses anak didik terhadap prasarana pendidikan seperti ruang baca (perpustakaan), dan akses anak didik terhadap pendidikan (perolehan pendidikan). Berdasarkan hasil wawancara dari guru di Kabupaten Gowa disimpulkan bahwa setiap siswa anak laki-laki dan perempuan diberikan kesempatan yang sama untuk memeroleh atau memanfaatkan semua fasilitas pendidikan yang ada di sekolah tanpa terkecuali, misalnya ruang baca, ruang olah raga, buku, ruang laboratorium, dan sebagainya. Hal ini berarti tidak ada perbedaan perlakuan dari guru kepada siswa perempuan dan siswa laki-laki terhadap akses prasarana pendidikan di sekolah. Misalnya untuk fasilitas perpustakaan, dengan tidak adanya perlakuan secara berbeda memperlihatkan bahwa kunjungan perpustakaan berimbang antara siswa perempuan dan siswa laki- laki. Selain itu, juga didapatkan informasi dari guru bahwa metode pembelajaran kepada siswa dilakukan sama antara laki dan perempuan dengan kata lain tidak ada perlakuan yang berbeda apakah anak didik laki-laki ataukah anak didik perempuan. Hasil studi untuk kasus di Kabupaten Gowa tidak sejalan dengan studi yang dilakukan oleh Fitriani dan Habibullah (2012) yang menyatakan bahwa faktor askes pendidikan merupakan faktor penyebab ketimpangan gender di bidang pendidikan di Kecamatan Majalaya di Kabupaten Kerawang. Namun studi ini sejalan Fitriani dan Habibullah (2012) untuk kasus di Kabupaten Jeneponto.

Informasi dari guru menyatakan adanya beberapa anak yang memutuskan untuk tidak bersekolah (putus sekolah) di SD Inpres Cambaya di Kabupaten Gowa, bukan disebabkan oleh tidak adanya peluang atau perbedaan akses untuk memperoleh atau memanfaatkan fasilitas di sekolah, namun lebih disebabkan oleh faktor lingkungan yakni siswa yang bersangkutan (perempuan) merasa paling besar diantara anak-anak lainnya, sehingga malu ke sekolah. Selain itu, ditemukan pula anak laki-laki yang putus sekolah karena sudah tertarik dengan penghasilan sendiri yang diperoleh dari hasil penjualan kantong plastik. di tempat pelelangan ikan (TPI).

Dari sudut pandang orang tua, setiap orang tua memberikan kesempatan yang sama pada setiap anak tanpa kecuali. Baik anak laki-laki maupun anak perempuan diberi peluang yang sama untuk menempuh pendidikan. Hal ini dapat dilihat jumlah anak didik perempuan yang menempuh pendidikan relative berimbang dengan jumlah anak laki-laki (80:95). Dengan demikian, secara umum dapat disimpulkan dua hal khusus untuk wilayah penelitian di Kabupaten Gowa: (i) tidak ada masalah dari aspek akses anak didik sekolah terhadap fasilitas pendidikan di sekolah, (ii) orang tua tidak membedakan anak mereka baik lakilaki maupun perempuan untuk menempuh pendidikan hingga pada jenjang yang lebih tinggi. Hal ini berarti ketimpangan gender di bidang pendidikan di Kabupaten Gowa tidak disebabkan oleh faktor akses sebagaimana di temukan oleh Fitriani dan Habibullah (2012).

Fakta yang sedikit berbeda dengan masyarakat pesisir di Kabupaten Jeneponto, dimana ditemukan sejumlah responden yang memberikan perlakuan yang berbeda terhadap anaknya untuk memperoleh pendidikan. Terdapat kecenderungan anak perempuan lebih diutamakan untuk bersekolah daripada anak laki-laki. Karena laki-laki adalah tumpuan keluarga sehingga laki-laki diberi peluang yang lebih besar untuk mencari nafkah. Hal ini erat kaitannya dengan faktor budaya sehingga ditemukan ada kasus siswa tidak melanjutkan sekolah karena faktor budaya tersebut. Hasil temuan ini juga terjadi di daerah lainnya sebagaimana ditemukan oleh Fitriani dan Habibullah (2012); dan Natasha (2013). Natasha (2013) menemukan bahwa kesenjangan gender di bidang pendidikan terjadi akibat dari masih adanya pemikiran masyarakat yang ortodoks dan parsial sehingga menyebabkan salah satu pihak merasa dirugikan.

Hasil wawancara dari responden (orang tua murid) mengatakan bahwa anak laki-laki adalah tumpuan harapan bagi rumah tangga sehingga dengan kondisi ekonomi yang tidak mencukupi maka anak laki-laki harus membantu orang tuanya mencari nafkah. Hal ini terlihat bahwa banyak anak laki-laki yang bekerja sebagai abo-abo (pengumpul rumput laut) bahkan putus sekolah karena desakan ekonomi orang tua. Temuan ini sedikit berbeda studi lainnya dimana kaum laki-laki justru didorong untuk melanjutkan pendidikan sekolah dibandingkan dengan kaum perempuan (Pettalongi, 2009; Widodo, 2006). 
Namun dari pendapat Guru mengatakan bahwa setiap siswa diberikan kesempatan yang sama untuk memanfaatkan perpustakaan atau ruang baca. Namun karena pada umumnya siswa perempuan lebih rajin, maka terlihat siswa perempuan lebih mendominasi perpustakaan yang disediakan oleh sekolah. Ini berarti dari sisi akses tidak ada masalah, namun fakta ini harus menjadi perhatian bagi guru untuk menempuh langkah-langkah yang responsive gender. Karena jika hal demikian dibiarkan tentu akan berdampak pada perbedaan pengetahuan antara laki-laki dan perempuan.

Jika dikaitkan dengan ada kasus siswa yang putus sekolah di Jeneponto, itu bukan karena faktor akses tetapi faktor lain (temuan ini sama dengan di Kabupaten Gowa). Informasi ini terungkap oleh guru kelas 4 di SD 81 Tanrusampe melaporkan bahwa terdapat anak putus sekolah dengan jenis kelamin laki-laki yang diakibatkan karena masalah psikologis dimana si anak tidak ingin melanjutkan sekolahnya lagi karena merasa tidak pintar dibandingkan dengan teman-teman sekelasnya. Temuan ini sejalan dengan Natasha (2013) yang mengatakan bahwa faktor kesenjangan gender di bidang pendidikan disebabkan oleh banyak faktor dan salah satu diantaranya adalah faktor psikologi. Hal yang berbeda dengan siswa di kelas VI juga terdapat kasus siswa putus sekolah (laki-laki) disebabkan oleh siswa bersangkutan bekerja sebagai pengumpul rumput laut dan merasa sudah mampu untuk menghasilkan uang sehinga motivasi untuk kembali bersekolah tidak ada. Pihak guru telah melakukan upaya-upaya untuk memotivasi agar siswanya kembali bersekolah namun tidak berhasil.

Dari faktor akses, penyebab kesenjangan gender seperti partisipasi sekolah perempuan lebih tinggi, jumlah anak laki-laki putus sekolah lebih banyak, anak didik perempuan lebih rajin, dan sebagainya nampaknya berbeda antara kedua lokasi penelitian. Di Gowa pada umumnya tidak ada masalah dari faktor akses, namun di Jeneponto sebagian kesenjangan gender disebabkan oleh budaya dan akses.

\section{Faktor Partisipasi}

Faktor partisipasi di lokasi penelitian baik di Kabupaten Gowa maupun di Kabupaten Jeneponto, siswa perempuan umumnya berpartisipasi lebih aktif di dalam kelas daripada siswa laki-laki. Berdasarkan informasi guru wali, umumnya siswa perempuan lebih kritis, lebih rajin mengerjakan pekerjaan rumah, aktif belajar berkelompok, dan interaksi dengan guru lebih sering dilakukan dibandingkan dengan siswa laki-laki. Hal ini didukung oleh pendapat responden (orang tua) bahwa sekitar 21,1\% responden mengatakan bahwa anak perempuan lebih rajin dibandingkan dengan anak laki-laki dan hanya sekitar 5,3\% responden mengatakan anak laki-laki lebih rajin, serta $73,6 \%$ responden berpendapat bahwa anak lakilaki dan perempuan sama-sama rajin. Meskipun hanya sekitar $21,1 \%$ responden yang berpendapat bahwa anak perempuan lebih rajin, namun hal tersebut didukung oleh fakta yang menunjukkan bahwa tingkat prestasi yang dicapai anak perempuan selalu lebih tinggi daripada anak laki-laki. Umumnya yang memegang peringkat I sampai III besar ditempati oleh siswa perempuan terutama pada tingkat SD kelas IV, kelas V dan kelas VI untuk kasus di Kabupaten Gowa. Guru juga mengakui bahwa ada juga siswa laki-laki yang menonjol namun relatif sedikit.

Tingginya partisipasi anak didik perempuan dibandingkan dengan laki-laki disebabkan oleh peran orang tua. Kurangnya keterlibatan orang tua untuk memberi motivasi anak didik mereka telah berimplikasi terhadap prestasi yang dicapai dan juga berimplikasi terhadap kecenderungan anak didik untuk putus sekolah. Misalnya, lokasi penelitian di Kabupaten Gowa, anak putus sekolah karena orang tua mereka lebih banyak mencurahkan waktu bekerja sebagai penjual di pasar tradisional sehingga perannya untuk mengawasi anak di bidang pendidikan sangat kurang (informasi dari salah satu Guru SD Inpres Cambaya). Peran kedua orang tua (suami dan istri) sangat dibutuhkan untuk mendorong agar anak mereka dapat menempuh pendidikan. Jika hanya salah satu orang tua yang berperan nampaknya tidak memberikan hasil yang memuaskan, misalnya ditemukan informasi dari responden bahwa anaknya putus sekolah sejak tiga tahun yang lalu dan menurut ibu (istri), upaya yang telah dilakukan cukup banyak akan tetapi si anak yang bersangkutan tetap bekerja dan bersama-sama bapak (suami) untuk mencari nafkah. Ini menunjukkan bahwa bapak (suami) mendukung anaknya untuk putus sekolah. Jika dicermati kondisi tersebut, berarti peran si bapak sangat kurang.

Selain orang tua, peran guru terhadap anak didik tak kalah pentingnya. Di Kabupaten Gowa ditemukan ada kasus siswa yang putus 
sekolah dan menurut informasi dari salah seorang guru yang mengatakan bahwa telah diupayakan tetapi tidak berhasil untuk membujuk anak kembali untuk bersekolah. Hal ini mengindikasikan bahwa masih perlu upaya serius agar anak yang putus sekolah kembali bersekolah. Dapat disimpulkan bahwa terjadinya kesenjangan gender misalnya putus sekolah laki-laki di lokasi penelitian disebabkan oleh faktor partisipasi anak yang bersangkutan dan partisipasi dari orang tua. Temuan yang sama di Kabupaten Gorontalo bahwa kesenjangan gender yang terjadi pada angka putus sekolah dan partisipasi sekolah dikontribusi oleh faktor pendidikan masyarakat, kemiskinan, sosiokultural, dan jarak sekolah sebagaimana ditemukan oleh Nusantari dan Ahmad. Berbeda dengan studi Ichwayudi (2013) menemukan adanya kesenjangan gender di bidang pendidikan disebabkan oleh faktor pemimpin atau penentu kebijakan.

\section{Faktor Kontrol}

Terjadinya kesenjangan gender juga disebabkan oleh kurangnya kontrol dari orang tua dan guru. Misalnya di Kabupaten Gowa, prestasi siswa perempuan lebih tinggi daripada siswa laki-laki dan terdapat kasus siswa laki-laki yang putus sekolah, hal tersebut disebabkan oleh kurangnya kontrol atau pengawasan yang dilakukan oleh orang tua. Hal ini disebabkan oleh karena kebanyakan orang tua mereka baik suami maupun istri bekerja di pasar seharian penuh sehingga perhatian terhadap anak sangat kurang.

Kurangnya perhatian orang tua terhadap anak didik erat kaitannya dengan keterlibatan orang tua dalam menentukan keputusan anak untuk bersekolah atau melanjutkan sekolah. Di Kabupaten Gowa disimpulkan bahwa sebagian besar orang tua (suami dan istri) secara bersama-sama untuk memutuskan pendidikan anak tanpa membedakan jenis kelamin. Namun ada pula beberapa responden yang mengatakan bahwa hanya istri atau suami saja yang menentukan tingkat pendidikan anak. Sebesar $78,9 \%$ responden memberikan jawaban keputusan tentang pendidikan anak dilakukan secara bersama-sama oleh suami istri,sekitar 15,9\% keputusan dilakukan oleh istri saja dan 5,2\% hanya oleh suami saja.

Berbeda dengan di wilayah pesisir Kabupaten Jeneponto (Pabiringa dan Biringkasi) bahwa yang mengambil keputusan untuk anak bersekolah didominasi oleh istri sekitar $46 \%$ jawaban responden, dan hanya $43 \%$ ditentukan secara bersamasama, serta selebihnya $11 \%$ keputusan dari suami. Perbedaan cara pengambilan keputusan orang tua terhadap pendidikan di kedua lokasi penelitian disebabkan oleh perbedaan tingkat pengetahuan atau latar belakang pendidikan orang tua. Temuan yang sama di Kabupaten Gororntalo bahwa tingkat pendidikan masyarakat turut mempengaruhi kesenjangan gender di bidang pendidikan (Nusantari dan Ahmad). Pada umumnya, tingkat pengetahuan responden di Tompobalang (disekitar SD Inpres Cambaya) cukup baik karena wilayahnya termasuk sebagai wilayah perkotaan. Sementara di Desa Pabiringa dan Biringkasi merupakan wilayah pesisir dan jauh dari pusat perkotaan.

Kesenjangan gender tidak hanya disebabkan semata-mata oleh pengawasan orang tua tetapi juga guru terutama guru kelas. Karena yang paling mengetahui sikap dan prilaku anak setiap hari di sekolah adalah guru kelas. Oleh karena itu, setiap guru kelas wajib untuk melakukan pengawasan terhadap setiap anak didik. Seperti kasus yang terjadi di lokasi penelitian di Kabupaten Jeneponto bahwa terdapat murid perempuan di kelas 4 yang putus sekolah. Setelah ditelusuri ternyata si anak bersangkutan mengalami pertumbuhan fisik yang lebih cepat dibandingkan dengan teman lainnya. Adanya keputusan si anak didik tersebut terindikasi kurangnya pengawasan dari guru. Semestinya guru wali kelas dapat melakukan sesuatu yakni menyentuh si anak didik dari sisi emosional dan memberikan pemahaman kepada teman-teman kelasnya untuk tidak melakukan sikap yang tidak disenangi oleh si anak perempuan tersebut. Ini berarti faktor komunikasi terhadap anak didik cukup penting sebagaimana dikemukakan oleh Jeanny Marya Fatima, (2014). Keterlibatan orang tua murid dan guru terhadap anak didik sangat membantu mengatasi kesenjangan gender di bidang pendidikan. Hal ini diperkuat oleh pernyataan Zumrotun dan Ismi, 2014 dalam seminar Pendidikan Berbasis Adil Gender di Salatiga bahwa pendidikan persperspektif gender harus dimulai dalam lingkungan keluarga dan ditambahkan oleh Ismi (2014) bahwa peran serta komite sekolah dibutuhkan dalam mewujudkan pendidikan peka gender.

\section{Faktor Manfaat}

Hasil analisis menunjukkan bahwa kesenjangan gender yang ditemukan di 
kedua lokasi penelitian bukan disebabkan oleh karena adanya manfaat yang tidak adil dari fasilitas pendidikan. Misalnya tingginya partisipasi anak didik perempuan mengerjakan tugas, berdiskusi didalam kelas, memanfaatkan perpustakaan bukan karena ada perbedaan fasilitas bagi anak didik laki-laki dan perempuan. Namun sangat tergantung pada anak didik bersangkutan untuk memanfaatkan fasilitas yang disediakan. Oleh karena faktor partisipasi anak didik perempuan lebih tinggi maka anak didik perempuan memperoleh manfaat yang lebih banyak daripada anak laki-laki. Fasilitas yang disediakan oleh pemerintah pada dasarnya untuk dimanfaatkan secara adil oleh semua siswa. Demikian halnya dengan angka putus sekolah laki-laki lebih banyak daripada perempuan bukan juga faktor manfaat dari penyediaan fasilitas yang tidak adil bagi anak didik laki dan perempuan.

Namun perlu dicermati lebih jauh seperti di Kabupaten Jeneponto ditemukan bahwa ruang baca lebih banyak dimanfaatkan oleh siswa perempuan. Apakah karena fasilitas ruang baca tersebut lebih banyak mengakomodir kepentingan anak perempuan atau sebaliknya, misalnya ketersediaan buku yang diminati oleh anak laki-laki lebih sedikit. Adanya tingkat partisipasi siswa perempuan lebih tinggi daripada laki-laki berimplikasi terhadap prestasi yang dicapai oleh anak didik perempuan. Jika terdapat kecenderungan hal tersebut, maka untuk mengiliminir kondisi tersebut, kiranya pihak pemerintah Dinas Pendidikan perlu menganalisis faktorfaktor penyebab dan memikirkan langkahlangkah konkrit agar ruang baca dapat pula dimanfaatkan oleh siswa laki-laki.

Dengan mencermati ke empat faktor akses, partisipasi, kontrol, dan manfaat terhadap pendidikan dan fasilitas pendidikan dapat disimpulkan bahwa kesenjangan gender sebagian disebabkan oleh faktor partisipasi yang kurang (dari orang tua, guru, dan anak didik sendiri), faktor akses yang kurang dari orang tua khususnya di Jeneponto, dan faktor konrol terutama kontrol dari orang tua untuk kedua lokasi. Fakta ini menunjukkan bahwa untuk mengurangi kesenjangan gender maka keterlibatan dan sinergitas orang tua dan guru sangat diperlukan.

\section{Pemahaman Responden tentang Gender dan Pendidikan Berwawasan Gender}

Berdasarkan hasil wawancara orang tua murid pada seluruh lokasi penelitian dapat disimpulkan bahwa pemahaman responden tentang gender dan pendidikan berwawasan gender cukup rendah. Hal ini dapat dilihat dari beberapa pertanyaan yang terkait dengan istilah gender tidak dapat dijawab oleh responden. $100 \%$ responden rumah tangga menjawab "tidak tahu" dengan konsep dan pentingnya gender dalam pembangunan. Rendahnya pemahaman orang tua terhadap gender atau isu-isu gender juga terjadi di daerah lain (Gayatri, 2008). Gayatri (2008) menemukan bahwa kebanyakan orang tua dan anak di lokasi penelitian (Kecamatan Cariu, Kabupaten Bogor, Jawa Barat) masih memandang adanya pelabelan negatif yang dilekatkan pada diri perempuan.

Namun temuan yang menarik ketika muncul pertanyaan yang menyangkut pendidikan anak mereka baik yang terkait dengan proses pengambilan keputusan untuk anak masuk jenjang pendidikan maupun keberlanjutan anak ke jenjang pendidikan yang lebih tinggi. $\mathrm{Di}$ atas $50 \%$ responden menyatakan pendapat bahwa yang memutuskan anak untuk masuk sekolah maupun melanjutkan pendidikan adalah secara bersama-sama antara suami dan istri. Hal ini berarti faktor kontrol terhadap anak di bidang pendidikan cukup tinggi. Akan tetapi tetap pula ditemukan sejumlah responden yang berpendapat istri yang memutuskan dengan alasan suami bahwa anak adalah tugas istri dan istri ditinggal di rumah. Sementara alasan bahwa suami memutuskan karena suami adalah kepala keluarga dan pencari nafkah sehingga kondisi ekonomi diketahui oleh suami. Jika dicermati data dan informasi tersebut dapat dikatakan bahwa sebagian responden sudah paham tentang gender dan sebagian lainnya belum paham. Adanya perbedaan tersebut disebabkan oleh latar belakang pendidikan yang berbeda. Temuan ini konsisten dengan temuan studi sebelumnya yang menyatakan bahwa pendidikan masyarakat (dalam hal ini orang tua) turut menentukan kuat tidaknya pengambilan keputusan didalam lingkungan rumah tangga (Mufidah, 2011). Ada beberapa alasan yang dikemukan oleh orang tua terkait dengan keputusan untuk melanjutkan sekolah ke jenjang yang lebih tinggi yaitu tergambar didalam Tabel 2.

Pertanyaan yang detail tentang ada atau tidak ada perbedaan perlakuan orang tua antara anak perempuan dan anak laki-laki dalam menempuh pendidikan, dijawab oleh responden secara berbeda. Untuk lokasi di Kabupaten Gowa, pada umumnya responden 
mengatakan tidak ada perbedaan keduanya sama-sama dituntut untuk menempuh pendidikan ke jenjang yang lebih tinggi bahkan sampai pada perguruan tinggi sepanjang mampu dibiayai. Berbeda dengan lokasi penelitian di Kabupaten Jeneponto karena merupakan wilayah pesisir nampaknya banyak responden memberikan perlakukan yang berbeda antara anak laki-laki dan anak perempuan dalam menempuh pendidikan. Beberapa responden mengatakan bahwa anak perempuan tidak perlu sekolah terlalu tinggi karena pada akhirnya kembali menjadi ibu rumah tangga.

\section{Tabel 2}

Alasan Responden untuk Keberlanjutan Studi Anak

\begin{tabular}{|c|l|}
\hline No & \multicolumn{1}{|c|}{ Alasannya } \\
\hline $\mathbf{1}$ & Demi masa depan anak \\
\hline $\mathbf{2}$ & $\begin{array}{l}\text { Pendidikan anak harus melebihi } \\
\text { orangtuanya }\end{array}$ \\
\hline $\mathbf{3}$ & Agar cita-cita anak bisa tercapai \\
\hline $\mathbf{4}$ & Karena ilmu tidak pernah habis \\
\hline $\mathbf{5}$ & Pendidikan sangat penting \\
\hline $\mathbf{6}$ & Agar mendapat pekerjaan yang lebih baik \\
\hline
\end{tabular}

Sumber : Data Primer, diolah 2014

Pertanyaan lain yang mengindikasikan pemahaman orang terhadap gender adalah pembagian kerja anak didalam rumah tangga. Dari seluruh responden di lokasi penelitian Kabupaten Jeneponto, mayoritas anak perempuan mengerjakan pekerjaan domestik, sementara anak laki-laki cenderung tidak diberikan beban untuk menyapu, mencuci piring, memasak, ke pasar, dan sebagainya. Hal ini menunjukkan bahwa beban kerja anak perempuan lebih tinggi daripada anak lakilaki. Hal ini sejalan dengan temuan Marzuki, 2008; Mufidah, 2011) bahwa perempuan lebih diidentikkan dengan urusan domestik dibandingkan dengan publik. Untuk itu, yang penting untuk diperhatikan ke depan agar kesenjangan gender tidak terulang adalah peran dan keterlibatan orang tua agar anak laki-laki tetap termotivasi untuk bersekolah dan lebih rajin agar sama-sama dapat menikmati hasil pembangunan khususnya di bidang pendidikan.

Selain itu, faktor lingkungan dan budaya juga berpengaruh terhadap persepsi responden terhadap pendidikan dan pembagian kerja dalam keluarga. Budaya patriarki yang masih kuat cenderung menempatkan posisi laki-laki lebih tinggi daripada perempuan sehingga menjadi faktor kesenjangan gender dalam masyarakat untuk menempuh pendidikan. Hal tersebut tergambarkan pada pola pendidikan anak dalam keluarga dimana mayoritas masyarakat setempat memandang bahwa pekerjaan rumah tangga hanya dikerjakan oleh perempuan dan laki-laki tidak diperkenakan untuk mengerjakannya.

Dengan memperhatikan Gambar 2 , sekitar $2,2 \%$ responden menganggap pekerjaan menyapu adalah dikerjakan oleh laki-laki dan $66,6 \%$ pekerjaan diluar rumah merupakan pekerjaan laki-laki. Namun demikian, juga ditemukan persepsi bahwa pekerjaan di dalam rumah tangga tidak hanya dikerjakan oleh perempuan saja atau lakilaki saja tetapi dikerjakan secara bersamasama. Salah satu responden mengatakan bahwa siapa saja diantara keduanya yang punya waktu luang, maka dialah yang mengerjakannya. Dengan mencermati data tersebut, dapat disimpulkan bahwa budaya

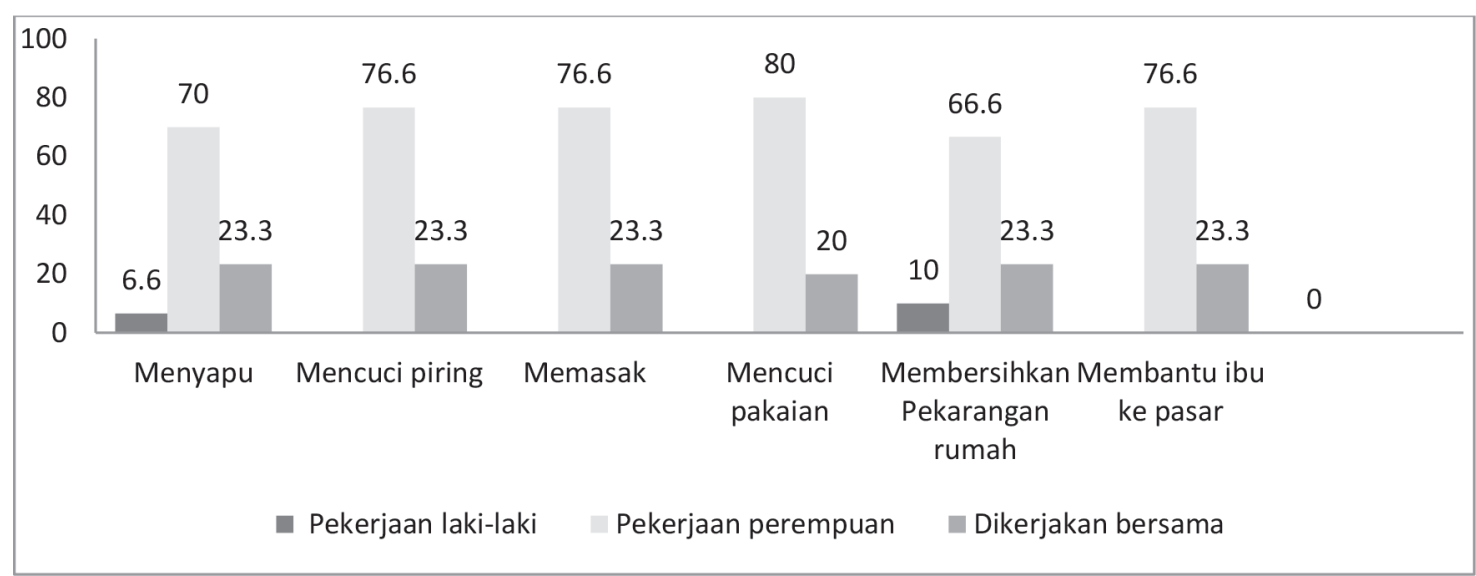

Sumber: Data primer diolah, 2014

Gambar 2. Pembagian kerja anak dalam keluarga berdasarkan jenis kelamin 
patriarki masih kuat di wilayah pesisir khususnya di wilayah penelitian di Kabupaten Jeneponto yang cenderung memposisikan laki-laki punya kedudukan yang lebih tinggi daripada perempuan didalam rumah tangga, sehingga semua pekerjaan domestik dalam rumah tangga dikerjakan oleh perempuan. Hal ini tentu saja memunyai dampak yang kurang menguntungkan kepada anak perempuan.

Pemahaman tentang gender juga ditanyakan kepada guru SD 81 Tanrasampe, (Guru kelas 1 sampai kelas 6). Hasilnya adalah $100 \%$ responden menjawab tidak tahu dengan istilah tersebut. Akan tetapi pada praktiknya para guru memberikan perlakuan yang sama kepada setiap murid perempuan dan laki-laki dalam proses mengajarnya dan tidak ada pembedaan antar satu dengan yang lain. Hal ini berarti pemahaman konsep gender tidak diketahui namun dalam praktiknya terindikasi ada pemahaman namun masih sangat rendah dan masih perlu ditingkatkan. Setiap guru kelas harus memahami karakter, aspirasi, pengalaman, dan kebutuhan setiap murid atau siswanya. Jika terdapat siswa laki-laki yang malas atau memperoleh nilai yang rendah, atau tidak lulus, atau tidak cepat menyerap materi dari guru, maka guru seyogyanya memberikan perhatian sesuai dengan pengalaman dan kebutuhan siswa yang bersangkutan. Dengan kata lain, setiap siswa tidak dibiarkan untuk tertinggal dibandingkan dengan siswa yang lain. Contoh, jika ruang baca lebih banyak dimanfaatkan oleh anak perempuan, maka harus dipikirkan strategi apa sehingga anak siswa laki-laki juga dapat memanfaatkan ruang baca tersebut.
Dari gambaran tersebut di atas, maka dapat ditarik kesimpulan bahwa pada umumnya orang tua dan guru belum memahami istilah gender dan pendidikan yang berwawasan gender. Oleh karena itu, peningkatan pemahaman terhadap gender, PUG bgai orang tua dan guru menjadi sangat penting.

\section{Model Penguatan Kelembagaan PUG berbasis Sinergi}

Untuk mewujudkan kesetaraan dan keadilan gender bidang pendidikan maka perlu model sinergitas penguatan kelembagaan pengarusutamaan gender yang mana selama ini penguatan kelembagaan PUG belum melibatkan orang tua murid dan pihak guru di sekolah. Straegi PUG dapat mewujudkan kesetaraan dan keadilan gender bidang pendidikan bilamana semua komponen stakeholder terlibat (Jahidi, 2004; Zumrotun dan Ismi, 2014). Rendahnya tingkat pemahaman orang tua dan guru terhadap pendidikan yang berwawasan gender dan PUG cukup signifikan berkontribusi terhadap ketimpangan gender di lokasi penelitian. Oleh karena itu, penguatan kelembagaan PUG seyogyanya tidak hanya sampai pada aparat pemerintah tingkat kabupaten tetapi perlu keterlibatan guru dan orang tua murid. Dengan demikian, untuk mewujudkan kesetaraan dan keadilan gender di bidang pendidikan, maka model sinergitas penguatan PUG perlu dilakukan sebagaimana tertera dalam Gambar 3.

Penetapan model sinergitas tersebut dihasilkan dari beberapa temuan dilapangan yaitu: (1) Akar masalah kesenjangan gender di lokasi penelitian umumnya disebabkan oleh

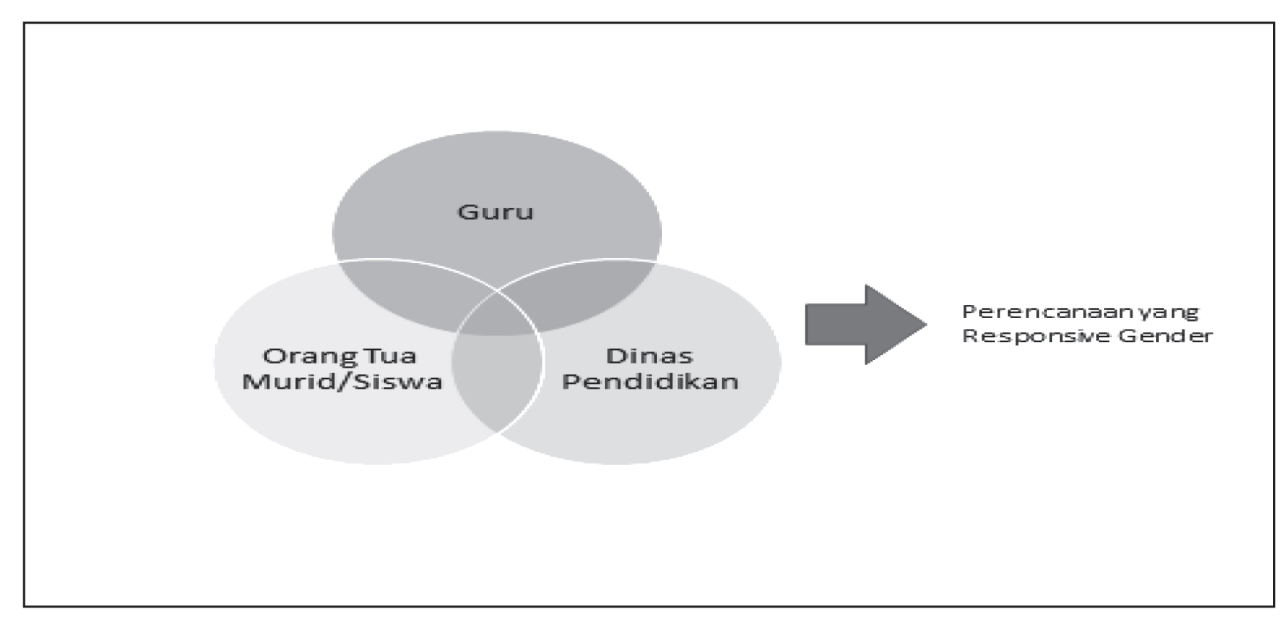

Sumber: Tim Peneliti, 2014

Gambar 3

Model Sinergitas Dalam Mewujudkan Kesetaraan dan Keadilan Gender Bidang Pendidikan 


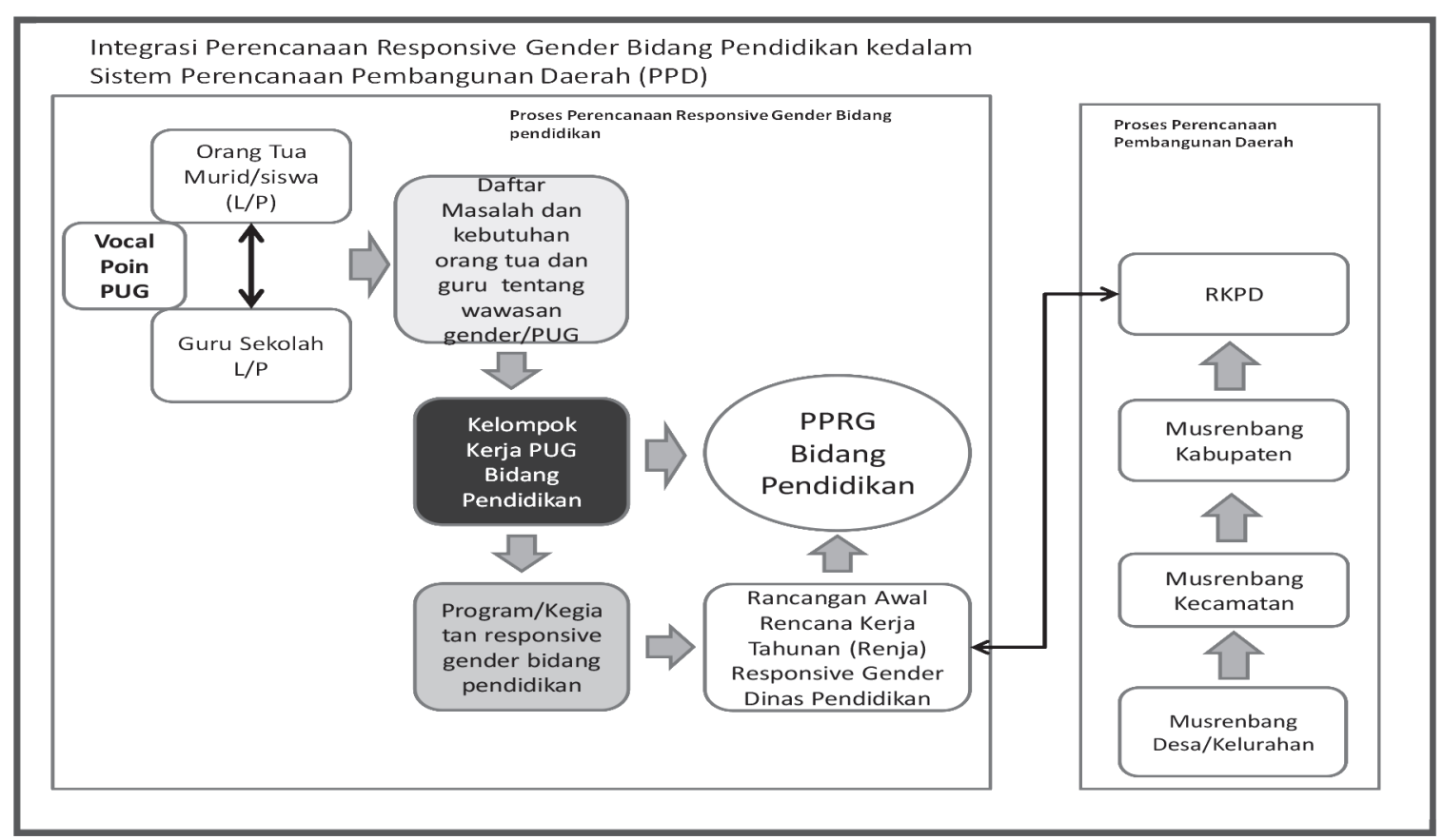

Sumber: Tim Peleniti, 2014

Gambar 4. Integrasi Perencanaan responsive Gender Bidang Pendidikan ke dalam Sistem Perencanaan Pembangunan Daerah (PPD)

faktor akses, partisipasi, kontrol, budaya, dan faktor ekonomi. Oleh karena itu, untuk mengatasi kesenjangan gender maka yang perlu disentuh adalah faktor-faktor penyebab tersebut; (2) Dari aspek tenaga pendidik (sampel Guru SD), mereka belum memahami gender dan belum pernah terlibat dalam kegiatan pelatihan perencanaan dan penganggaran yang responsive gender. Padahal salah satu yang berkontribusi utama dalam memberikan masukan terkait dengan prilaku anak didik di Sekolah baik laki maupun perempuan adalah guru. Oleh karena di dalam proses penyusunan dokumen perencanaan, dimana guru tidak dilibatkan secara langsung, maka permasalahan yang terkait dengan isu gender tidak diintegrasikan kedalam perencanaan. Untuk memperkuat kelembagaan PUG berperan didalam menerapkan strategi PUG maka perlu sinergitas antara tim penyusun dokumen perencanaan dan guru; (3) Dari aspek rumah tangga sasaran. Di dalam lingkup rumah tangga, orang tua sebagai orang pertama yang mengetahui dan memahami karakter, sikap, dan prilaku anak di rumah. Setelah anak menempuh pendidikan ke Sekolah Dasar, maka orang kedua yang memahami prilaku mereka adalah guru kelas, dan setelah itu kepala sekolah. Dengan demikian, penyusunan perencanaan dan penganggaran yang responsive gender (PPRG), tidak hanya diberikan kepada orang-orang tertentu yang dalam hal ini aparat dinas pendidikan, namun perlu diikutsertakan para orang tua murid dan guru secara langsung. Para orang tua dan murid secara intens melakukan pertemuan untuk mengetahui permasalahan yang terjadi pada anak baik anak laki-laki maupun perempuan. Untuk itu, setiap sekolah perlu menyusun perencanaan yang responsive gender di sekolah masing-masing.

Selain itu, dalam lingkup Dinas Pendidikan perlu membuat regulasi dalam bentuk kebijakan yang bersyarat bahwa setiap sekolah harus menyusun perencanaan yang responsive gender yang dipandu/dibina oleh vokal point dari Dinas pendidikan atau anggota Pokja dari Dinas Pendidikan. Untuk lebih mengoperasionalkan PUG melalui Perencanaan dan Penganggaran yang responsive gender, maka kelompok kerja PUG bersama vokal point harus lebih aktif menjalankan tugas dan fungsinya. Sebagai Vokal Point diberi insentif tersendiri untuk berkunjung ke sekolah (sesuai jenjang pendidikan) untuk melakukan pertemuan baik formal maupun informal kepada guru dan orang tua murid. Pertemuan antara guru dan orang tua murid dapat dimanfaatkan pada saat pengambilan rapor untuk menekan biaya operasional. Vokal point dapat membagi diri ke masing-masing sekolah. Alternatif lain 
antara lain; vokal point dapat mengadakan pertemuan khusus untuk mengindentifikasi permasalahan anak didik baik di lingkungan sekolah maupun di lingkungan rumah tangga terutama anak didik yang bermasalah dan berpotensi bermasalah (putus sekolah). Hasil pertemuan tersebut melahirkan sejumlah data dan informasi yang dituangkan ke dalam satu dokumen Daftar Masalah dan Kebutuhan Orang Tua dan Murid yang terkait dengan Gender.

Daftar Kebutuhan yang dimaksud akan menjadi informasi bagi Pokja PUG bidang pendidikan dalam menjalankan tugas dan fungsinya yaitu menyusun program dan kegiatan yang responsive gender di bidang pendidikan. Program dan kegiatan ini sekaligus menjadi rancangan awal penyusunan renja yang responsive gender dan yang berkontribusi terhadap penerapan penyusunan Perencanaan dan Penganggaran yang responsive gender seperti tertera dalam Gambar 4.

Hasil dari proses ini akan tergambar sejumlah informasi penting tentang penyebab kesenjangan gender misalnya faktor budaya, kurangnya akses pendidikan dari orang tua dan guru, kurangnya partisipasi orang tua dan guru, kurangnya kontrol, atau ada ketersediaan fasilitas secara tidak adil sehingga mempengaruhi faktor manfaat, dan atau karena lingkungan internal Guru atau Dinas Pendidikan yang menetapkan program dan kegiatan yang tidak responsive gender. Informasi tersebut selanjutnya menjadi input dalam penguatan kelembagaan PUG bidang pendidikan.

\section{Simpulan dan Saran}

Jenis kesenjangan gender yang terjadi di lokasi penelitian yaitu partisipasi siswa perempuan lebih tinggi daripada laki-laki, siswa laki-laki yang putus sekolah secara kuantitas lebih banyak daripada perempuan, siswa perempuan lebih berprestasi daripada laki-laki, dan pekerjaan domestik rumah tangga lebih didominasi oleh perempuan. Penyebab kesenjangan gender tersebut adalah karena faktor partisipasi, faktor akses, dan faktor kontrol, ekonomi, serta faktor budaya.

Tingkat pemahaman orang tua murid terkait dengan gender dan PUG secara umum masih sangat rendah. Misalnya di Kabupaten Jeneponto masih ditemukan sejumlah responden yang memperlakukan secara berbeda antara anak laki-laki dan perempuan di bidang pendidikan, sehingga akses laki-laki terhadap pendidikan sangat terbatas. Berbeda dengan responden di Kabupaten Gowa, dimana secara umum sejumlah responden telah memahami gender dari sisi praktek. Selain orang tua murid, tingkat pemahaman guru terkait dengan gender dan PUG juga masih sangat rendah.

Untuk mengeliminir kesenjangan gender di bidang pendidikan, maka dikembangkan sebuah model penguatan kelembagaan PUG yang berbasis sinergitas antara orang tua murid, guru, dan Dinas Pendidikan. Model tersebut, selanjutnya berkontribusi terhadap kelompok kerja PUG dalam menyusun perencanaan dan penganggaran yang responsive gender di bidang pendidikan. Model tersebut secara operasional diterapkan pada dua level yaitu level orang tua murid tentang pendidikan rumah tangga yang berwawasan gender, dan penerapan pada level guru dan pokja PUG tentang penyusunan perencanaan dan penganggaran yang responsive gender.

Disarankan agar model sinergitas yang dihasilkan melalui studi ini dapat ditindaklanjuti oleh pemerintah daerah dalam hal ini Dinas Pendidikan dan Kebudayaan dalam bentuk: penguatan kelompok kerja PUG dengan melibatkan orang tua murid dan guru secara bersinergi, membuat kebijakan yang mengarahkan setiap sekolah menyusun perencanaan dan penganggaran yang responsive gender, sosialisasi kepada orang tua murid dan guru tentang pentingnya gender dalam pembangunan dan pendidikan yang berwawasan gender dalam rumah tangga.

\section{Daftar Pustaka}

Bulkis, (2008). Analisis Gender dalam Pembangunan Per Sektor dan Rencana Aksi di Kota Balikpapan Tahun 2006-2011, Balikpapan.

Bulkis, (2009). Derita Karya dan Harapan Perempuan Papua, Buku.

Bulkis, (2007). Pemberdayaan Perempuan Di Sulawesi Barat, Kerjasama Bappeda Sulawesi Barat dan Pusat Penelitian Gender UNHAS.

Bulkis, Sitti; Tenriawaru, dan Nursini (2012) "Model Pemberdayaan Kepala Rumah Tangga Miskin Berperspektif Gender dalam Upaya Pengentasan Kemiskinan di Kabupaten Bone dan Soppeng. Laporan Penelitian tidak dipublikasi, LP2M UNHAS.

David, W.Pits; Elizabeth; Vicky, and 
Sanjay.K.Pandey (2006) What do Women Want? Men, Women, and Job Satisafaction in the Public Service. Working Paper Georgia State University Andrew Young School of Policy Studies.

Edy Budiharso, (2010). Pemberdayaan Kelompok Perempuan dalam Pengembangan Ekonomi Perdesaan. Http: www.docstoc.com/docs/36711790/ pemberdayaankelompokperempuan. 29/9/2011

Fatimah, J M. (2014).Kesetaraan Gender Melalui Komunikasi Keluarga Untuk Meningkatkan Akses Pendidikan Bagi Anak Perempuan Dalam Lingkaran Kemiskinan. MIMBAR (Jurnal Sosial dan Pembangunan). Vol.30.No.2. http://ejournal.unisba.ac.id/ index.php/mimbar/article/view/75 3 akses 8 Jan 2015

Feldstein, Hilary Sims and Janice Jiggins (eds.) (1994). Tools for the Field: Methodologies Handbook for Gender Analysis in Agriculture. West Hartford: Kumarian Press.

Fitrianti, dan Habibullah, (2012). Ketidaksetaraan Gender Dalam Pendidikan Studi pada Perempuan di Kecamatan Majalaya Kabupaten Karawang. Jurnal Sosikonsepsia. Vol 17. No.01. pp 85-99

Gayatri, (2008). Faktor Dan Dampak Ketimpangan Pendidikan Perempuan Dalam Kehidupan Perempuan (Kasus: Kecamatan Cariu, Kabupaten Bogor, Jawa Barat). http://repository.ipb.ac.id/ bitstream/handle/123456789/1874/ A08fga. pdf; jsessionid $=391$ F9ED10C5C D3F53ADD62BD869FA249? sequence $=5$ retrieved 21 Mei 2015

Ichwayudi, (2013). Kesetaraan Gender Di Lembaga Pendidikan Islam Pasuruan (Studi atas Gender Mainstreaming pada MI Wali Songo dan SD Muhammadiyah Gempol, Pasuruan.http://eprints. uinsby.ac.id/151/1/Executive $\% 20$ SummaryP. \%20BUdi\%20ihwayudi.pdf. Tanggal akses 21 Mei 2015

Jahidi, I.(2004). Gender Mainstreaming di Bidang Pendidikan: Antara Peluang dan Tantangan. MIMBAR (Jurnal Sosial dan Pembangunan), Tersedia pada: <http:// ejournal.unisba.ac.id/index.php/mimbar/ article/view/145>. Tanggal Akses: 08 Jan. 2015.

Marzuki, (2008). Studi Tentang Kesetaraan Gender Dalam Berbagai Aspek Makalah disajikan dalam Sosialisasi Kesetaraan Gender Kegiatan KKN Mahasiswa UNY (Kelompok 18) di PKBM "Sekar Melati" Sinduadi Mlati Sleman tanggal
24 Desember 2008. http://staff.uny. ac.id/sites/default/files/pengabdian/ dr-marzuki-mag/dr-marzuki-mag-studitentang-kesetaraan-gender-dalamberbagai-aspek.pdf. Akses 21 Mei 2015

Moser, Caroline O. N. (1993). Gender Planning and Development: Theory, Practice, and Training. London: Routledge

Mufidah, (2011). Strategi Implementasi Pengarusutamaan Gender Bidang Pendidikan Islam dalam Jurnal Al Tahrir Volume 11 Nomor 2 November 2011. http://download.portalgaruda.org/ article. php ?article $=182838 \& \mathrm{val}=6315$ \&title=Strategi\%20Implementasi\%20 Pengarusutamaan\%20Gender\%20 Bidang\%20Pendidikan\%20Islam

Narayan, Deepa. November, (1995). Toward Participatory Research. World Bank Technical Paper No.307. Washington, D.C.:The World Bank.

Natasha, Harum, (2013). Ketidaksetaraan Gender Bidang Pendidikan: Faktor Penyebab, Dampak, dan Solusi. Jurnal marwah Vol.XII No.1 Juni 2013.

Nusantari dan Ahmad. Kajian Penyebab Kesenjangan Gender Berdasarkan Partisipasi dan Angka Putus Sekolah di Provinsi Gorontalo. http://www. google.co.id/url?sa $=t \& r c t=j \& q=\&$ esrc $=s \&$ source $=w e b \& c d=2 \&$ ved $=$ OCCIQFjAB\&url=http $\% 3 A \% 2 F \% 2 F r e$ pository.ung.ac.id\%2Fget\%2Fsimlit_ res\%2F1\%2F156\%2FKajian-PenyebabKesenjangan-Gender-BerdasrkanPrtisipasi-Dan-Angka-Putus-Sekolah-DiPropinsi Gorontalo. pdf\&ei=3yFdVajWHN ChugSbgYH4Bw\&usg = AFQjCNFpOZGa6 RfoOofGOugBI5ND4Ht6zQ\&sig2 =XoCVZ7 P57ezSeR32YQDfkw. Akses 21 Mei 2015

Nursini, dkk (2011). "Evaluasi Kebijakan Responsive Gender Bidang Pendidikan pada Dinas Pendidikan di Kabupaten Barru dan Pangkep Sulawesi Selatan". Laporan Penelitian Puslitbang Kependudukan dan Gender UNHAS.

Nurfitriah, (2011). Pemberdayaan Perempuan Pesisir Melalui Pemberdayaan Ekonomi Masyarakat Pesisir di Kab. Bantul. Retrived 29/9/2011.http:litabamas-sb.info/ pemberdayaanperempuanpesisir

Pettalongi, Sagaf S. (2009). Gender Education (Rekonstruksi Pendidikan Yang Bias Gender). http://download.portalgaruda. org/article.php\%3Farticle\%3D185676\%2 6val\%3D6439\%26title\%3DGENDER\%252 OEDUCATION\%2520. Akses 21 Mei 2015

Pierre-Richard Agenor Otaviano Canuto, (2013). "Gender Equality and Economic 
Growth in Brazil A Long-Run Analysis. The World Bank Poverty Reduction and Economic Management Network January 2013. Policy Working Paper 6348

Rahminawati, N.. (2001). Isu Kesetaraan Laki-Laki dan Perempuan (Bias Gender). MIMBAR (Jurnal Sosial dan Pembangunan). Tersedia pada: <http:// ejournal.unisba.ac.id/index.php/mimbar/ article/view/48>. Tanggal Akses: 08 Jan. 2015.

Uche Udoko, (2010). Unpaid Care Work and Gender Inequality within Household in Africa. Gender Economics Vol.1

Wakeman, Wendy, (1995). Gender Issues Sourcebook for Water and Sanitation. UNDP-World Bank Water and Sanitation Program/PROWWESS. Washington, D.C.: The World Bank.

Widodo, Wahyu. (2006). Analisis Situasi Pendidikan Berwawasan Gender Di Propinsi Jawa Timur. Jurnal Humanity Vol 1 No.2. 2006. http://ejournal.umm.ac.id/index. php/humanity/article/view/108. Akses 21 Mei 2015

World Bank. (1994). Analyzing Gender Issues in the World Bank's Country Economic Memoranda: An Example from Uganda. World Bank "Enhancing Women's Participation in Economic Development". World Bank Policy Paper. Washington, D.C. Zumrotun dan Ismi, (2014). Ketidakadilan Gender Terjadi dalam Pendidikan. dalam Seminar Pendidikan Berbasis Adil Gender di Gedung Korpri Salatiga, Selasa (31/5). http://suaramerdeka.com/v1/index. php/pendidikan/newsdetail/48637/ Ketidakadilan-Gender-Terjadi-dalamPendidikan (21 Mei 2015). 